\author{
Waldemar Woźniak* \\ Uniwersytet Szczeciński
}

\title{
ANALIZA BEZROBOCIA W POLSCE W LATACH 2004-2014
}

\section{Streszczenie}

W pracy poruszono problematykę bezrobocia i bezrobotnych. Ukazano definicje bezrobocia, klasyfikacje bezrobocia, jego skutki, instrumenty polityki zatrudnienia oraz sposoby przeciwdziałania bezrobociu. Zaprezentowano dane statystyczne dotyczące liczby pracujących w Polsce, liczby ofert pracy, liczby bezrobotnych zarejestrowanych, stopy bezrobocia i liczby absolwentów szkół wyższych.

Słowa kluczowe: bezrobotni z wyższym wykształceniem, klasyfikacja bezrobocia, instrumenty bezrobocia

\section{Wprowadzenie}

Od przeszło dwudziestu lat bezrobocie w Polsce jest faktem. Transformacja gospodarcza „późnego” socjalizmu w kapitalizm i włączenie Polski w globalną strukturę zależności gospodarczych sprawiły, że trudno sobie wyobrazić powrót do sytuacji, gdy zdecydowana większość populacji Polaków miała zagwarantowaną możliwość pracy zawodowej. Bez wątpienia w wielu przypadkach była to praca źle

\footnotetext{
*Adres e-mail: walwoz8@wp.pl.
} 
zorganizowana i słabo płatna, choć z indywidualnej perspektywy wielu osób o niskich kwalifikacjach zapewniała minimalny poziom życia i nie wymagała starań, aby ją otrzymać i utrzymać. Celem pracy jest przybliżenie problematyki bezrobocia w Polsce, ukazanie skutków bezrobocia, zaprezentowanie instrumentów polityki zatrudnienia oraz przedstawienie danych statystycznych odnośnie do: liczby ofert pracy, liczby bezrobotnych zarejestrowanych, stopy bezrobocia i liczby absolwentów szkół wyższych.

\section{Problematyka bezrobocia w Polsce}

W najczęściej przyjmowanych przez ekonomistów definicjach bezrobocia podkreśla się, że ,zjawisko to oznacza sytuację, w której część osób w wieku produkcyjnym, zdolnych i gotowych do pracy na typowych warunkach występujących w gospodarce, pozostaje bez pracy, mimo podejmowania poszukiwań pracy" (Kwiatkowski 2005, s. 391).

Bezrobocie stanowi jeden z istotnych elementów przemian systemu społeczno-gospodarczego w naszym kraju. Jest to swoisty koszt społeczny procesu transformacji systemowej. Zakres, struktura oraz negatywne konsekwencje tego zjawiska stają się coraz bardziej odczuwalne nie tylko przez osoby pozostające bez pracy i ich rodziny, ale również przez całe społeczeństwo.

Dramat bezrobocia, nędzy, a często i głodu jest udziałem nie tylko jednostek, ludzi bezpośrednio dotkniętych tymi zjawiskami, ale całych ich rodzin, często także dużych środowisk, zarówno wiejskich, jak i miejskich. Bezrobocie obniża nieraz wręcz katastroficzne warunki życia, wzmaga różne sytuacje konfliktowe, maksymalizuje poczucie niepewności jutra, zwiększa skłonności do nadużyć, kradzieży, przemocy itp. (Żebrowski 2006, s. 79-80).

W literaturze można spotkać różne klasyfikacje bezrobocia. Dość powszechny jest podział na bezrobocie związane z niedopasowaniami strukturalnymi oraz bezrobocie związane z nadwyżką całkowitej podaży siły roboczej nad całkowitym popytem na siłę roboczą.

Bezrobocie związane z niedopasowaniami strukturalnymi występować może zarówno w sytuacji równowagi na rynku pracy, czyli gdy całkowita podaż siły roboczej jest równa całkowitemu popytowi na siłę roboczą, jak i w sytuacji nierówno- 
wagi na rynku pracy. Ten rodzaj bezrobocia obejmuje bezrobocie frykcyjne i bezrobocie strukturalne.

Bezrobocie frykcyjne stanowi nieredukowane minimum bezrobocia $\mathrm{w}$ dynamicznej gospodarce. Powstaje ono w związku z powolnością przystosowań struktury podaży siły roboczej i struktury popytu na siłę roboczą na niedoskonale funkcjonującym rynku pracy. W dynamicznej gospodarce ustawicznie pojawiają się niedopasowania (frykcje) między wolnymi miejscami pracy a wolną siłą roboczą, ponieważ ciągle zachodzą procesy dotyczące tworzenia i likwidacji miejsc pracy, napływu i odpływu siły roboczej z rynku pracy oraz zmiany miejsc pracy przez pracowników. W następstwie tych procesów zawsze występuje pewna liczba wolnych miejsc pracy i osób bezrobotnych. W związku z tym, że informacje od pracodawców i poszukujących pracy są niedoskonałe, musi upłynąć jakiś czas, zanim bezrobotni znajdą czekające na nich miejsca pracy.

Bezrobocie strukturalne powstaje w rezultacie niedopasowań struktury podaży siły roboczej i popytu na nią, głównie w aspektach kwalifikacyjnym, zawodowym i regionalnym. U podstaw niniejszych niedopasowań leżą procesy upadku albo rozwoju pewnych branż i gałęzi, związane z tendencjami postępu technicznego i kierunkami międzynarodowego podziału pracy.

Bezrobocie związane z nadwyżką całkowitej podaży siły roboczej nad całkowitym popytem na siłę roboczą wynikać może zarówno ze wzrostu podaży siły roboczej, jak i redukcji popytu na siłę roboczą. W tym drugim przypadku, związanym z osłabieniem ogólnej aktywności gospodarczej, mamy do czynienia z bezrobociem koniunkturalnym. Wśród ekonomistów istnieją zasadnicze rozbieżności poglądów w kwestii przyczyn tego bezrobocia. Keynesiści upatrują ich w niedostatecznym popycie na towary i dlatego ten typ bezrobocia określany jest często mianem bezrobocia związanego z niedostatecznym popytem, zaś neoklasycy thumaczą to bezrobocie głównie zbyt wysokimi płacami (Kwiatkowski 2005, s. 395-396).

Wyróżnia się następujące skutki bezrobocia:

a) społeczno-psychologiczne, takie jak:

- frustracja poszczególnych osób, wywołana niemożnością uczestnictwa w życiu gospodarczym kraju,

- pogorszenie stanu zdrowia ludzi; szerzenie się różnorodnych chorób, trudności z zakupem leków będące wynikiem braku pieniędzy, wzrost prób samobójczych i samobójstw, 
- wzrost patologii społecznych,

- obniżenie poziomu siły kapitału społecznego (Solak 2010, s. 178);

b) ekonomiczne, takie jak:

- obniżenie materialnego poziomu życia, szerzenie się sfery ubóstwa,

- koszty wynikające z luki powstałej między PKB nominalnym i potencjalnym,

- koszty związane z drenażem pieniędzy publicznych w postaci wypłacanych zasiłków dla bezrobotnych, zasiłków w formie pomocy społecznej oraz koszty wynikające z instytucjonalizacji rynku pracy,

- koszty ponoszone przez całe społeczeństwo, np. świadczenia socjalne, składki na ubezpieczenie społeczne, programy przeciwdziałania bezrobociu,

- wydatki publiczne związane z przechodzeniem na wcześniejsze emerytury osób zagrożonych utratą miejsc pracy,

- koszty związane z niepełnym wykorzystaniem czynników produkcji,

- straty budżetu państwa wynikające z niższych wpływów z podatku dochodowego od osób fizycznych, od osób pozbawionych pracy, a więc i wynagrodzenia,

- straty budżetu państwa z tytułu obniżenia dochodów z podatku od towarów i usług, gdyż bezrobotni, uzyskując niższe dochody, ograniczają konsumpcję,

- straty wynikające z występowania zjawiska zwanego „drenażem mózgów”, czyli koszty związane z emigracją młodych, wysoko wykształconych osób nieznajdujących pracy zgodnej z oczekiwaniami (Hajder 2008, s. 89-90).

Negatywne skutki bezrobocia mają zarówno wymiar ekonomiczny, społeczny, jak i psychologiczny. Ekonomiczne konsekwencje bezrobocia mogą być rozpatrywane z punktu widzenia jednostek oraz gospodarki. Od strony jednostkowej bezrobocie prowadzi głównie do gwałtownego spadku dochodów rodzin. Rodziny dotknięte bezrobociem w pierwszej kolejności ograniczają korzystanie z dóbr kulturalnych oraz rozrywki, co znacząco ogranicza aktywność społeczną, prowadząc jednocześnie do wycofywania się z życia towarzyskiego. Następnie bezrobotni i ich rodziny ograniczają do minimum korzystanie ze zorganizowanego wypoczynku i zaczynają ograniczać wydatki na żywność. Ponadto ograniczony jest dostęp do edukacji. Mam 
tu na uwadze przede wszystkim szkolnictwo wyższe. Sytuacja taka powoduje, że na bezrobociu tracą bezpośrednio nie tylko sami bezrobotni, ale również ich dzieci, którym ograniczone zostają szanse równego życiowego startu. Szczególnie ważne spośród wymienionych skutków bezrobocia jest ograniczenie dostępu do nauki, gdyż sprzyja ono zjawisku dziedziczenia bezrobocia.

Żyjące w biedzie i wykluczone społecznie jednostki utrwalają będący ich udziałem model egzystencji. Osoby bezrobotne i bezdomne nie umieją rozbudzić w sobie i w swoich dzieciach aspiracji edukacyjnych, kulturowych i zawodowych. Nie są w stanie zapewnić dzieciom wykształcenia, zadbać o ich dobrostan psychiczny, pozwalający wyrwać się ze spirali nędzy. Zjawisko to pogłębia się w rodzinach wielodzietnych, a zwłaszcza tam, gdzie bezrobocie dotknęło obojga rodziców.

Bezrobocie uderza w młodsze pokolenia. Bezrobotne dzieci bezrobotnych rodziców będą w przyszłości miały jeszcze mniejsze szanse na wyrwanie się z kręgu społecznej niemożności i włączenie się w nurt życia gospodarczego i kulturowego. Przyzwyczają się one do korzystania z pomocy opieki społecznej i narastają w nich postawy roszczeniowe (Furmanek 2008, s. 353-356).

Konieczne jest zatem znalezienie rozwiązań systemowych zatrzymujących młodych ludzi w kraju, na którego dalszy rozwój mogliby pracować. Otwieranie dla nich rynków pracy w krajach Unii Europejskiej powinno być traktowane jako forma dokształcania i doskonalenia zawodowego, nie zaś jako poważna propozycja programowa dla Polski. W procesie różnorodnych zmian w systemie edukacji nie należy zapominać o nowoczesnym systemie wychowania przez pracę do pracy. Powinien on być traktowany jako komponent powszechnego, ogólnego przygotowania zawodowego każdego Polaka. W tym zakresie niezbędne jest zerwanie z rozwiązaniami typowymi dla minionego systemu politycznego. Potrzebne jest nowe spojrzenie na funkcje wykształcenia ogólnego Polaków. W polskim systemie edukacji konieczne jest znalezienie i wdrożenie takich rozwiązań systemowych, które chronić będą Polaków przed konsekwencjami wykluczenia społecznego i cywilizacyjnego (Furmanek 2008, s. 361).

\section{Instrumenty polityki zatrudnienia}

Spośród wielu instrumentów polityki zatrudnienia wyróżnia się trzy zasadnicze grupy: służące wywieraniu wpływu na wzrost popytu na siłę roboczą, zmniejszają- 
ce podaż siły roboczej oraz dotyczące międzynarodowych porozumień w sprawie transferu siły roboczej (Woźniak 2012, s. 98).

Działaniami podejmowanymi w celu zwiększenia popytu na siłę roboczą są:

- „subwencjonowanie płac i zatrudnienia, mające na celu utrzymanie albo zwiększenie jego dotychczasowego poziomu w przedsiębiorstwach prywatnych,

- tworzenie nowych miejsc pracy w sektorze państwowym w myśl specjalnych programów zatrudnienia,

- popieranie szeroko rozumianej przedsiębiorczości, tworzenie nowych miejsc pracy w sektorze prywatnym poprzez popieranie małych i średnich przedsiębiorstw, lokalne inicjatywy wzrostu zatrudnienia oraz pomoc w tworzeniu własnych zakładów przez bezrobotnych lub zagrożonych bezrobociem,

- roboty publiczne" (Gogolewska 2006, s. 481-482).

Przeciwdziałanie bezrobociu w naszym kraju przez wzrost popytu na siłę roboczą stopniowo przybiera formy aktywne. Zasadniczym kierunkiem działań jest tworzenie nowych miejsc pracy. Niniejszemu celowi służą:

a) pożyczki z Funduszu Pracy:

- dla bezrobotnych chcących podjąć pracę na własny rachunek,

- dla zakładów pracy na tworzenie dodatkowych miejsc pracy,

- dla zwalnianych z PGR rolników na podjęcie pozarolniczej działalności gospodarczej;

b) szkolenia i przekwalifikowania zawodowe dla bezrobotnych i zagrożonych zwolnieniem z pracy (Gogolewska 2006, s. 487).

Innymi narzędziami do walki z bezrobociem są:

- prace interwencyjne i roboty publiczne organizowane przez organy samorządu lokalnego bądź terenowej administracji lokalnej,

- stwarzanie warunków rozwoju pozarządowych instytucji, których celem jest łagodzenie skutków bezrobocia (Agencja Inicjatyw Lokalnych, Bank Inicjatyw Gospodarczych, towarzystwa inwestycji społeczno-ekonomicznych, izby przemysłowo-handlowe, centra doskonalenia zawodowego, inkubatory przedsiębiorczości) (Gogolewska 2006, s. 486-487).

Ciekawą inicjatywą w dziedzinie łagodzenia skutków bezrobocia i pobudzania zawodowej aktywności bezrobotnych jest idea organizowania klubów pracy przy rejonowych urzędach pracy (Retowski 2011, s. 79). 
Poza działaniami mającymi na celu zwiększenie popytu na siłę roboczą w ramach polityki zatrudnienia stosowane są także działania, które ograniczają jej podaż. Do działań takich zalicza się:

a) zmniejszanie rozmiarów zasobów siły roboczej:

- umożliwienie wcześniejszego przejścia na emeryturę,

- przedłużanie okresu kształcenia,

- przedłużanie bądź wprowadzanie obowiązkowej służby wojskowej, jak również osłabianie aktywności zawodowej, np. przez zachęty dla kobiet do zajmowania się wychowywaniem dzieci;

b) zmniejszanie liczby godzin pracy:

- skracanie czasu pracy, wydłużanie urlopów,

- zmniejszanie liczby godzin ponadwymiarowych,

- zatrudnianie w niepelnym wymiarze czasu (Gogolewska 2006, s. 487-488).

Jest wiele form walki z bezrobociem. Do najpopularniejszych zalicza się:

- pośrednictwo pracy,

- poradnictwo zawodowe i informacja zawodowa,

- pomoc w aktywnym poszukiwaniu pracy,

- indywidualny plan działania,

- staże,

- szkolenia,

- przygotowanie zawodowe,

- finansowanie studiów podyplomowych,

- finansowanie kontynuowania nauki,

- prace interwencyjne,

- roboty publiczne,

- prace społecznie użyteczne,

- programy specjalne,

- bezzwrotne środki na podjęcie działalności gospodarczej,

- dodatki aktywizacyjne,

- refundacja kosztów opieki nad dzieckiem do 7 roku życia lub osobą zależną,

- refundacja kosztów wyposażenia lub doposażenia stanowiska pracy dla skierowanego bezrobotnego (Wsparcie w powrocie 2010, s. 7),

- różnego rodzaju programy rządowe, np. program 50+. 
Polska po wstąpieniu do Unii Europejskiej włączyła się do realizacji wspólnych programów europejskich, wśród których podstawową rolę pełni Europejska Strategia Zatrudnienia oraz strategia lizbońska. Do zasadniczych celów powyższych strategii należy osiągnięcie (Nowak, Sokół 2009):

- pełnego zatrudnienia (zgodnie ze strategią lizbońską jest to zatrudnienie, które nie tylko wyklucza koniunkturalne i strukturalne bezrobocie, lecz również wysoką nieaktywność zawodową),

- wysokiej produktywności i jakości pracy (przez co należy rozumieć pracę wysoko kwalifikowaną, w nowoczesnych działach gospodarki opartej na wiedzy, jak również w działach tradycyjnych, poddanych restrukturyzacji),

- spójnego rynku pracy, co wyklucza znaczące jego zróżnicowanie.

Rynek pracy w Polsce nie spełnia jednak tych kryteriów, a zmiany, które dokonują się w ostatnim okresie, nie wskazują na powstanie mechanizmu przyczyniającego się do jednoczesnego osiągnięcia wszystkich celów.

\section{Analiza rynku pracy w latach 2004-2014}

Podstawowe informacje z zakresu rynku pracy przedstawiono na rysunkach 1-6. Na rysunku 1 ukazano liczbę pracujących w Polsce w latach 2004-2014.

Rysunek 1. Pracujący w Polsce w latach 2004-2014 [tys.]

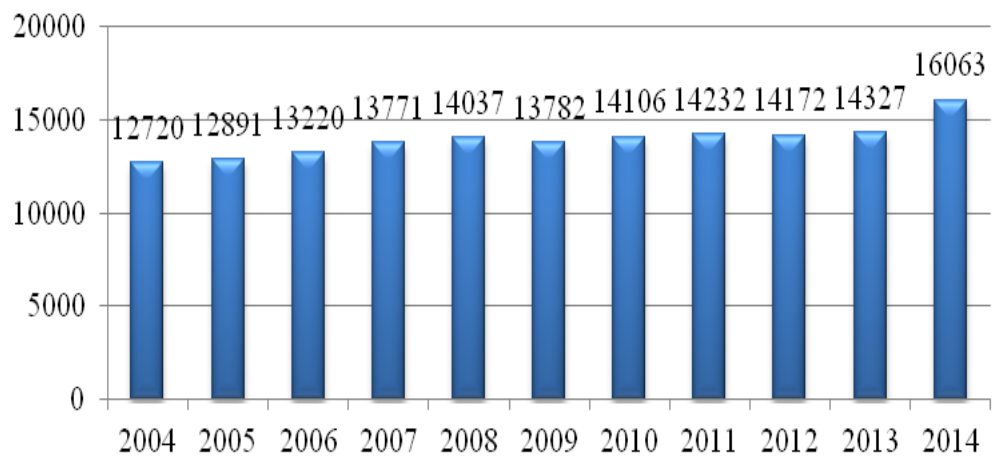

Źródło: opracowanie własne na podstawie roczników statystycznych Rzeczypospolitej Polskiej. 
Z danych zawartych na rysunku 1 wynika, że liczba pracujących poza niewielkimi wahaniami w latach 2008-2009 i 2011-2012 systematycznie rosła, od 12720 tys. osób w roku 2004 do 16063 tys. osób w roku 2014.

W ostatnich latach odnotowuje się coraz większą liczbę ofert pracy. Mimo to sytuacja na rynku pracy jest $\mathrm{w}$ dalszym ciągu trudna. Bezrobocie nadal utrzymuje się na wysokim poziomie. Wzrost liczby ofert pracy ma na celu zmniejszenie tego niekorzystnego zjawiska, liczba ofert pracy jest jednak o wiele mniejsza niż liczba bezrobotnych.

Liczbę ofert pracy, z których mogli skorzystać bezrobotni w latach 2004-2014, zaprezentowano na rysunku 2.

Rysunek 2. Oferty pracy w Polsce w latach 2004-2014 [tys.]

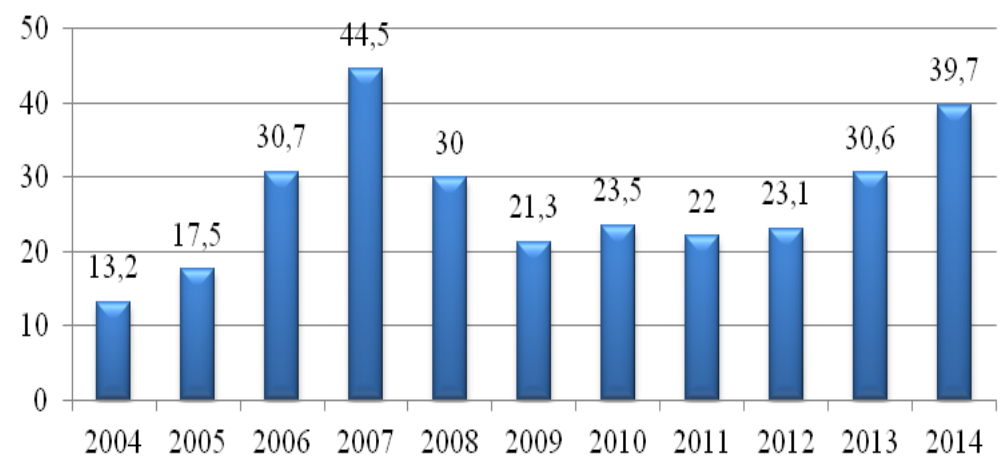

Źródło: opracowanie własne na podstawie roczników statystycznych Rzeczypospolitej Polskiej.

Analizując dane ukazane na rysunku 2, można zauważyć, że liczba ofert pracy dynamicznie rosła w latach 2004-2007, od 13,2 tys. ofert do 44,5 tys. ofert. Kolejne lata przyniosły gwałtowny spadek. W ostatnim okresie liczba ofert pracy ponownie rosła. W 2014 r. do dyspozycji osób bezrobotnych było blisko 40 tys. ofert.

Następstwem kryzysu gospodarczego na świecie był wzrost bezrobocia prawie we wszystkich krajach Unii Europejskiej. Konsekwencją tego było także pogorszenie sytuacji na rynku pracy w Polsce, choć siła tego wpływu była znacznie słabsza. Wiązało się to z tym, że w naszym kraju był wprawdzie osłabiony, ale jednak notowany wzrost gospodarczy, a inne kraje dotknęła głęboka recesja. 
Jeszcze kilka lat temu Polska miała najwyższy wskaźnik bezrobocia w Unii Europejskiej, a stopa bezrobocia była prawie 2 razy wyższa niż wskaźnik obliczony dla krajów UE.

Liczbę osób bezrobotnych zarejestrowanych w Polsce w latach 2004-2014 przedstawiono na rysunku 3.

Rysunek 3. Bezrobotni zarejestrowani w Polsce w latach 2004-2014 [tys.]

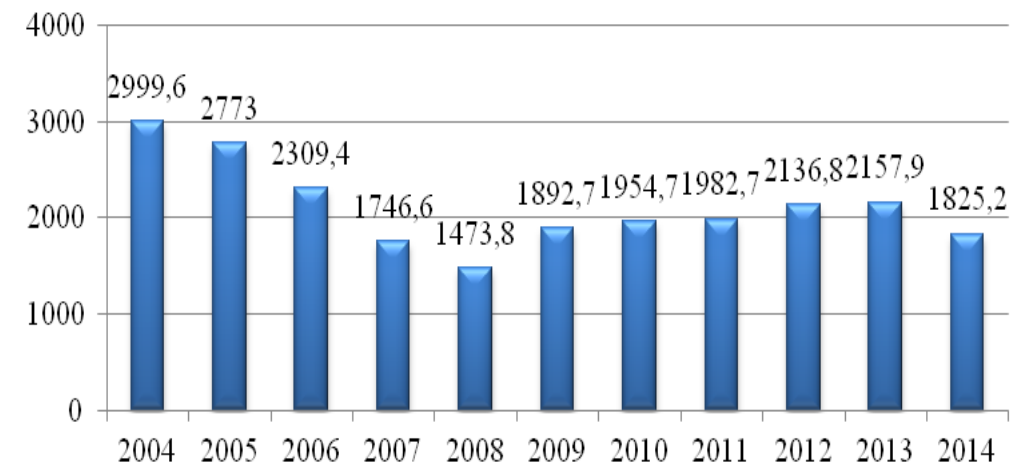

Źródło: opracowanie własne na podstawie roczników statystycznych Rzeczypospolitej Polskiej.

Analizując dane ukazane na rysunku 3, można zauważyć, że w latach 2004 -2008 liczba bezrobotnych zarejestrowanych wyraźnie się obniżała. W 2004 r. zarejestrowanych było w Polsce 2999,6 tys. bezrobotnych, a w roku 2008 ich liczba była o połowę mniejsza. W kolejnych latach odnotowywano niewielkie przyrosty liczby zarejestrowanych bezrobotnych, od 1892,7 tys. w roku 2009 do 2157,9 tys. w roku 2013. W roku 2014 liczba bezrobotnych obniżyła się do 1825,2 tys.

W ostatnich latach wzrosła liczba bezrobotnych mężczyzn. Było to spowodowane przede wszystkim wzrostem zwolnień w przetwórstwie przemysłowym. Bezrobocie w Polsce jest bardzo zróżnicowane terytorialnie, co jest następstwem nierównomiernego rozwoju społeczno-gospodarczego regionów i ich geograficznego położenia. Czynnikami, które mają wpływ na poziom rozwoju gospodarczego i sytuację na runku pracy, są: specyfika danego terenu, odległość od dużych aglomeracji i stopień rozwoju infrastruktury (Ministerstwo Pracy i Polityki Społecznej 2010, s. 3). 
Na rysunku 4 przedstawiono liczbę bezrobotnych zarejestrowanych z uwzględnieniem poziomu ich wykształcenia.

Rysunek 4. Bezrobotni zarejestrowani w Polsce według poziomu wykształcenia [\%]

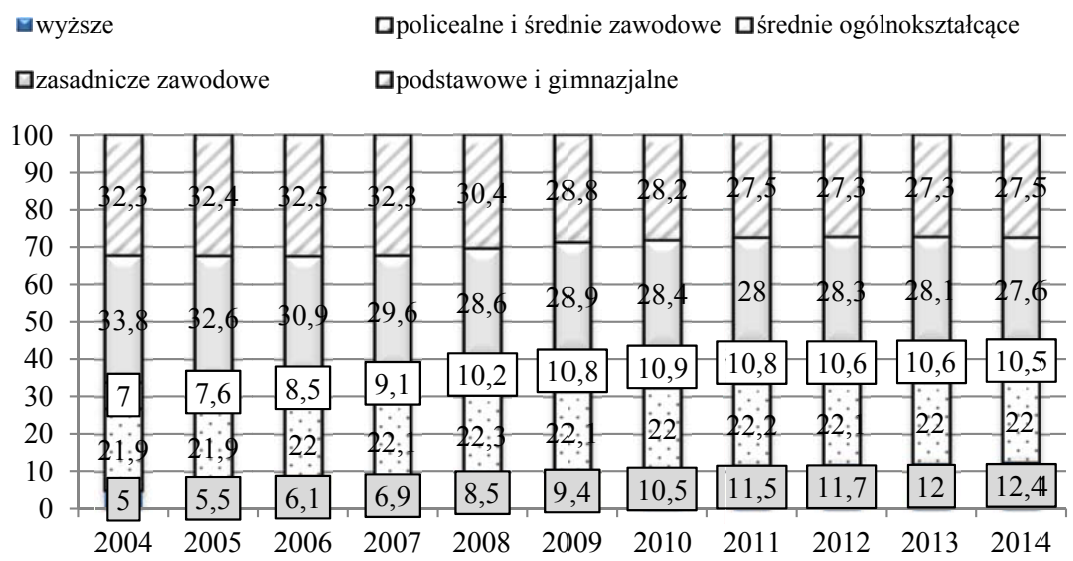

Źródło: opracowanie własne na podstawie małych roczników statystycznych Polski.

Z rysunku 4 wynika, że spośród bezrobotnych najmniejsze grono stanowily osoby z wykształceniem wyższym (od 5\% w 2004 r. do 12,4\% w 2014 r.) oraz średnim ogólnokształcącym (od 7\% w 2004 r. do 10,5\% w 2014 r.). Większą grupę bezrobotnych stanowiły osoby z wykształceniem policealnym i średnim zawodowym (od 21,9\% w 2004 i 2005 r. do 22\% w 2013 i 2014 r.), a największą osoby z wykształceniem podstawowym i gimnazjalnym (od 32,3\% w 2004 do 27,5\% w 2014 r.). Największy wzrost liczby zarejestrowanych bezrobotnych można zauważyć w przypadku osób z wykształceniem wyższym, gdyż ich liczba w analizowanym okresie wzrosła ponad dwukrotnie.

Na rysunku 5 ukazano stopę bezrobocia w Polsce w latach 2004-2013. 
Rysunek 5. Stopa bezrobocia rejestrowanego w Polsce w latach 2004-2013 [\%]

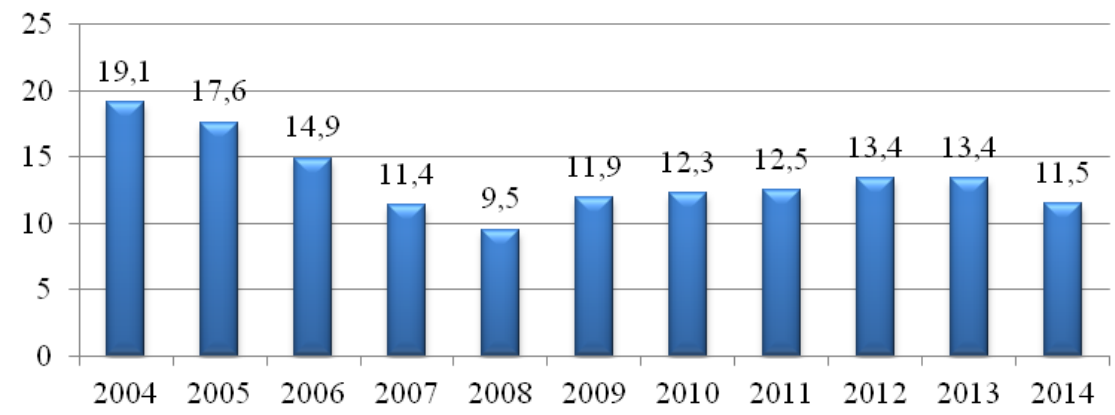

Źródło: opracowanie własne na podstawie roczników statystycznych Rzeczypospolitej Polskiej.

$\mathrm{Z}$ danych zawartych na rysunku 5 wynika, że stopa bezrobocia była najwyższa w 2004 r. i wynosiła 19,1\%. W latach 2005-2008 widoczny był wyraźny spadek stopy bezrobocia rejestrowanego. W $2008 \mathrm{r}$. spadła ona do 9,5\%, a więc była o połowę niższa niż w 2004 r. W latach 2009-2013 stopa bezrobocia rejestrowanego ponownie wzrosła o 2,5-3,5 punktu procentowego. W roku 2014 stopa bezrobocia obniżyła się o blisko 2 punkty procentowe w porównaniu do roku uprzedniego i wynosiła $11,5 \%$.

Na rysunku 6 przedstawiono liczbę absolwentów szkół wyższych w latach 2004-2014.

Rysunek 6. Absolwenci szkół wyższych w latach 2004-2014 [tys.]

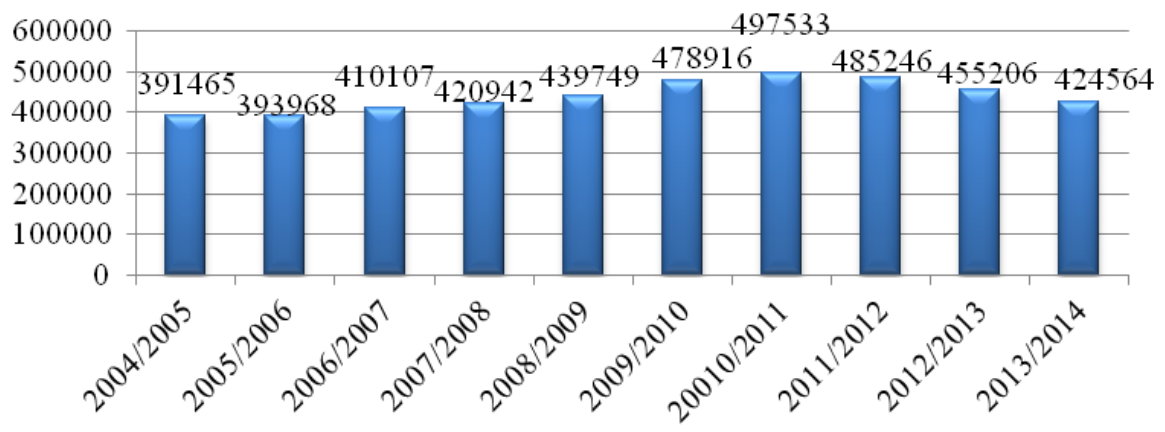

Źródło: opracowanie własne na podstawie roczników statystycznych Rzeczypospolitej Polskiej. 
Z rysunku 6 wynika, że liczba absolwentów szkół wyższych w latach 2004 -2011 systematycznie rosła od 391465 tys. do 497533 tys. Począwszy od roku szkolnego 2011/2012, odnotowano spadek liczby absolwentów.

\section{Podsumowanie}

Stopa bezrobocia w latach 2004-2008 rosła, a następnie obniżała się, liczba ofert pracy rosła, zwłaszcza w latach 2004-2007, pracujących przybywało, bez pracy było coraz mniej osób, a bezrobocie wśród osób z wyższym wykształceniem podwoiło się.

Rząd stoi przed trudnym zadaniem, gdyż wśród bezrobotnych jest wiele młodych osób, absolwentów szkół. Powinien on przeznaczać więcej pieniędzy z budżetu na walkę z tym niepokojącym zjawiskiem. Korzystne byłoby również obniżenie podatków dla osób prowadzących działalność gospodarczą, nie tylko przez pierwsze dwa lata. Może wówczas więcej osób zdecydowałoby się na założenie własnej firmy. Należałoby się również zastanowić, czy nie lepiej zlikwidować urzędy pracy, a środki przeznaczane na wypłaty dla urzędników przeznaczyć na dopłaty dla pracodawców czy inne bardziej korzystne cele.

Wnioski:

1. Liczba pracujących w Polsce poza niewielkimi wahaniami w latach 2008 2009 i 2011-2012 systematycznie rosła, od 12720 tys. osób w roku 2004 do 16063 tys. osób w roku 2014.

2. Liczba ofert pracy dynamicznie rosła w latach 2004-2007, od 13,2 tys. ofert do 44,5 tys. ofert. Kolejne lata przyniosły gwałtowny spadek. W ostatnim okresie liczba ofert pracy ponownie rosła. W 2014 r. do dyspozycji osób bezrobotnych było blisko 40 tys. ofert.

3. W latach 2004-2008 liczba bezrobotnych zarejestrowanych wyraźnie się obniżała. W 2004 r. zarejestrowanych było w Polsce 2999,6 tys. bezrobotnych, a w roku 2008 ich liczba była o połowę mniejsza. W kolejnych latach odnotowywano niewielkie przyrosty liczby zarejestrowanych bezrobotnych, od 1892,7 tys. w roku 2009 do 2157,9 tys. w roku 2013. W roku 2014 liczba bezrobotnych obniżyła się do 1825,2 tys.

4. W ostatnich latach wzrosła liczba bezrobotnych mężczyzn. Było to spowodowane przede wszystkim wzrostem zwolnień w przetwórstwie przemysłowym. 
5. Spośród bezrobotnych najmniejsze grono stanowiły osoby z wykształceniem wyższym (od 5\% w 2004 r. do 12,4\% w 2014 r.) oraz średnim ogólnokształcącym (od 7\% w 2004 r. do 10,5\% w 2014 r.). Większą grupę bezrobotnych stanowiły osoby z wykształceniem policealnym i średnim zawodowym (od 21,9\% w 2004 i 2005 r. do $22 \%$ w 2013 i 2014 r.), a największą osoby z wykształceniem podstawowym i gimnazjalnym (od 32,3\% w 2004 do 27,5\% w 2014 r.). Największy wzrost liczby zarejestrowanych bezrobotnych można zauważyć w przypadku osób z wykształceniem wyższym, gdyż ich liczba w analizowanym okresie wzrosła ponad dwukrotnie.

6. Stopa bezrobocia była najwyższa w 2004 r. i wynosiła 19,1\%. W latach 2005 -2008 widoczny był wyraźny spadek stopy bezrobocia rejestrowanego. W $2008 \mathrm{r}$. spadła ona do 9,5\%, a więc była o połowę niższa niż w 2004 r. W latach 2009 -2013 stopa bezrobocia rejestrowanego ponownie wzrosła o 2,5-3,5 punktu procentowego. W roku 2014 stopa bezrobocia obniżyła się o blisko 2 punkty procentowe w porównaniu do roku uprzedniego i wynosiła 11,5\%.

7. Liczba absolwentów szkół wyższych w latach 2004-2011 systematycznie rosła od 391465 tys. do 497533 tys. Począwszy od roku szkolnego 2011/2012, odnotowano spadek liczby absolwentów.

\section{Literatura}

Furmanek W. (2008), Zarys humanistycznej teorii pracy (z perspektywy pedagogiki pracy), Adam Marszałek, Toruń.

Gogolewska J. (2006), Regulowanie rynku pracy, w: Polityka gospodarcza, red. B. Winiarski, Wydawnictwo Naukowe PWN, Warszawa.

Hajder K. (2008), Wybrane uwarunkowania rozwoju bezrobocia w Polsce, Wydawnictwo Naukowe WNPiD UAM, Poznań.

Kwiatkowski E. (2005), Bezrobocie, w: Podstawy ekonomii, red. R. Milewski, E. Kwiatkowski, Wydawnictwo Naukowe PWN, Warszawa.

Ministerstwo Pracy i Polityki Społecznej (2010), Wsparcie w powrocie na rynek pracy. Biuletyn informacyjny dla bylych pracowników przemystu stoczniowego, Warszawa.

Nowak P., Sokół A. (red.) (2009), Uwarunkowania rozwoju potencjatu zatrudnienia a technologie informatyczne $i$ innowacje $w$ województwie zachodniopomorskim. Wnioski i rekomendacje dla regionu, Wojewódzki Urząd Pracy w Szczecinie, Szczecin. 
Retowski S. (2011), Bezrobocie i odpowiedzialność, Wydawnictwo Naukowe Scholar, Warszawa.

Solak A. (2010), Problematyka pracy i bezrobocia $w$ kontekście funkcjonowania rodziny, Wydawnictwo WSP TWP, Warszawa.

Woźniak M.G. (2012), Gospodarka Polski 1990-2011, t. 1, Wydawnictwo Naukowe PWN, Warszawa.

Żebrowski J. (red.) (2006), Rodzina polska na przełomie wieków, red. J. Wydawnictwo Uniwersytetu Gdańskiego, Gdańsk.

\title{
ANALYSIS OF UNEMPLYMENT IN POLAND IN YEARS 2004-2014
}

\begin{abstract}
Work brings into attention unemployment rate of people with higher education, the number of employed in Poland, the number of jobs, the number of registered unemployed and unemployment rate. In the paper the unemployment definitions, classifications unemployment, its effects, employment policy instruments and how to combat unemployment are presented.
\end{abstract}

Translated by Waldemar Woźniak

Keywords: unemployed with higher education, classification of unemployment, unemployment instruments

JEL Code: J64 